\title{
PENINGKATAN KUALITAS PELAYANAN DENGAN METODE SERVQUAL PADA PT. MEDIA PURNA ENGINEERING AREA PT. KRAKATAU STEEL (PERSERO) TBK
}

\author{
${ }^{1}$ Sahrupi, ${ }^{2 \cdot}$ Tb Asror Zulqornain \\ 1,2. Program Studi Teknik Industri, Fakultas Teknik, Universitas Serang Raya \\ 1.sahrupi@gmail.com
}

\begin{abstract}
A b strak
Tujuan penelitian ini adalah untuk peningkatan kualitas pelayanan terhadap kepuasan pelanggan PT. Media Purna Engineering area PT. Krakatau Steel (Persero) Tbk atas pelayanan jasa perawatan mekanik rotating, sistem hidrolik, kontruksi, dan piping. Adapun metode penelitian yang digunakan adalah metode service quality (servqual) untuk mengukur tingkat kepuasan dan kualitas pelayanan yang diberikan. Pengumpulan data dilakukan dengan menyebarkan kuesioner kepada karyawan PT. Krakatau Steel (Persero) Tbk dan dengan melakukan observasi secara mendalam tentang pelayanan jasa yang diberikan oleh PT. Media Purna Engineering kepada PT. Krakatau Steel (Persero) Tbk. Berdasarkan hasil penelitian menunjukkan bahwa kualitas pelayanan jasa PT. Media Purna Engineering tergolong baik, namun masih ada 3 atribut kualitas pelayanan yang masih perlu ditingkatkan atau dikembangkan kembali dari 25 atribut kualitas pelayanan diantaranya adalah kelengkapan dan kesiapan perlengkapan kerja, kecepatan dalam memberikan solusi, pekerja mempunyai pengetahuan dan keterampilan yang diperlukan pekerjaan. Kualitas yang dirasakan oleh mitra memberikan dampak pada kelangsungan bisnis yang berkelanjutan. Saran yang diberikan dalam penelitian ini adalah PT. Media Purna Engineering diharapkan dapat meningkatkan kualitas sumber daya manusia yang ada dengan tujuan meningkatkan kualitas pelayanan yang diberikan baik dari kelengkapan dan kesiapan peralatan kerja, daya tanggap pekerja, kepedulian akan keluhan-keluahan, kecepatan dalam bertindak memberikan solusi, ketepatan waktu penyelesaian pekerjaan, kesesuaian hari dan jam kerja, serta kualitas pelayanan lainnya yang dianggap perlu ditingkatkan guna kepuasan mitra perusahaan untuk kelangsungan bisnis yang berkelanjutan.
\end{abstract}

Kata Kunci : Kualitas Pelayanan, Service Quality (Servqual), Atribut Kualitas Pelayanan.

\section{PENDAHULUAN}

Seiring dengan berjalannya waktu, paradigma dalam menjalankan kegiatan bisnis perusahaan juga telah mengalami perkembangan. Di tahun 1970-an dan 1980-an konsep perencanaan strategis perusahaan kurang memperhatikan pada aspek kepentingan pelanggan, perusahaan hanya menekankan pada aspek strategi pemasaran. Sampai akhirnya disadari pentingnya konsep yang lebih menekankan pada perusahaan yang berwawasan dan mementingkan pelanggan. Konsep ini menempatkan pelanggan pada posisi yang semakin penting bagi perusahaan, karena konsumen dapat menjadi kunci bagi kesuksesan perusahaan.

Industri jasa telah berkembang tidak hanya pada jenisnya, akan tetapi semakin dominan dan beragamnya kebutuhan akan jasa tersebut. Dalam industri ini kualitas sangat penting bagi pihak perusahaan dan konsumen, karena kualitas barang ataupun jasa berpengaruh besar atau berhubungan dengan kepuasan pelanggan. Sehingga kualitas jasa dapat menjadi salah satu strategi yang penting dalam persaingan. Kualitas jasa dipengaruhi oleh dua faktor yaitu harapan dan kinerja yang dirasakan konsumen. Konsumen akan membandingkan harapan konsumen dan kinerja yang diberikan oleh perusahaan berupa pemberian pelayanan yang memuaskan. Bila harapan terpenuhi oleh pelayanan perusahaan, maka jasa tersebut dikatakan memiliki kualitas yang baik dan akan dapat memuaskan konsumen.

PT. Media Purna Engineering adalah perusahaan yang bergerak dalam bidang jasa perawatan mekanik rotating, sistem hidrolik, kontruksi, dan piping. Sehingga dalam usaha 
meningkatkan kepuasan pelanggan perlu memperhatikan kepuasan pelanggan karena pelanggan merupakan unsur yang terpenting dalam kegiatan jasa perawatan yang dikelola oleh perusahaan. Kepuasan pelanggan banyak dipengaruhi oleh berbagai faktor, diantaranya adalah kualitas pelayanan.

Pelayanan pada dasarnya mempunyai target atau sasaran yang sederhana saja yaitu dapat memenuhi apa yang diharapkan oleh pelanggan selaku pengguna layanan. Meskipun sasaran dari pelayanan cukup sederhana tetapi pelaksanaannya tidaklah semudah yang diucapkan karena untuk mencapai itu semua diperlukan suatu pelayanan yang berkualitas. Demikian pula dengan PT. Media Purna Engineering sebagai perusahaan pelayanan jasa harus dapat memberikan pelayanan yang berkualitas kepada pelanggannya. Karena dalam perusahaan pelayanan jasa masalah kualitas pelayanan menjadi masalah penting dan mendasar untuk meningkatkan kepuasan pelanggan selaku penggunaan layanan jasa.

Penelitian ini bertujuan memberikan satu metode pengukuran tingkat kepuasan pelanggan pada PT. Media Purna Engineering dengan menggunakan metode Service Quality (Servqual). Selanjutnya dari hasil pengukuran ini diharapkan dapat menjadi dasar perbaikan dan penyempurnaan layanan untuk masa yang akan datang guna mencapai peningkatan kepuasan pelanggan.

\section{METODE PENELITIAN}

Penelitian ini dilaksanakan di PT. Media Purna Engineering area PT. Krakatau Steel (Persero) Tbk. Penelitian dan pengolahan data dilakukan mulai bulan 20 Desember 2016 sampai dengan 20 Januari 2017. Diagram alir penelitian dapat dilihat pada Gambar 1.

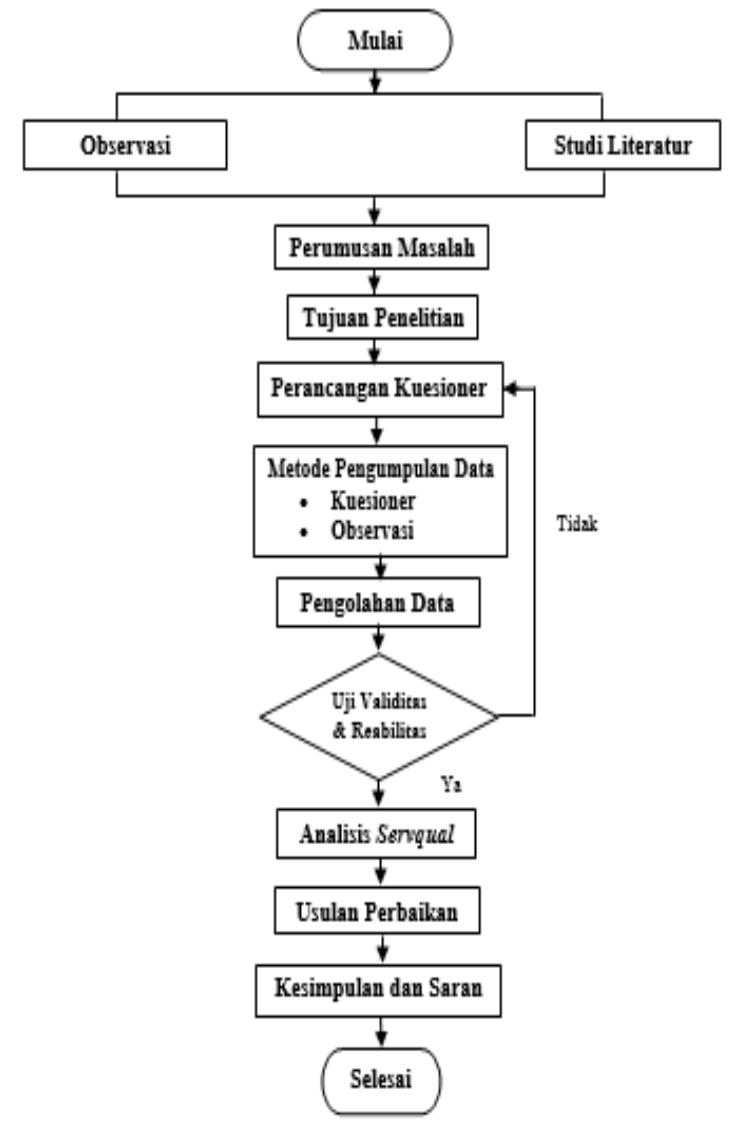

Gambar 1. Diagram Alir penelitian

Pada pengumpulan data penelitian ini menggunakan dua metode yaitu dengan penyebaran kuesioner yang selanjutnya data yang diperoleh dikumpulkan serta dengan melakukan observasi. Kuesioner merupakan teknik pengumpulan data yang dilakukan dengan cara memberi seperangkat pertanyaan atau pernyataan tertulis kepada responden untuk menjawabnya. Observasi ialah pengamatan dan pencatatan yang sistematis terhadap gejala-gejala yang diteliti. Kegiatan 
pengamatan terhadap objek penelitian ini untuk memperoleh keterangan data yang lebih akurat mengenai hal-hal yang diteliti serta untuk mengetahui relevansi antara jawaban responden dengan kenyataan yang terjadi dilapangan khususnya kualitas pelayanan PT. Media Purna Engineering area PT. Krakatau Steel (Persero) Tbk. Dalam pengindentifikasian atribut, atribut-atribut tersebut disesuaikan dengan kualitas layanan yang akan diteliti dengan merujuk terhadap lima dimensi Servqual. Skala pengukuran yang digunakan untuk penelitian ini adalah skala pengukuran likert yaitu skala yang digunakan untuk mengukur sikap, pendapat dan persepsi seseorang atau sekelompok tentang kejadian atau gejala sosial (Leoni, 2010). Pada penelitian ini menggunakan 5 jenjang kriteria yang berbeda dari masing-masing bagian kuesioner. Penelitian dilakukan dengan menyebarkan kuesioner dengan skala Likert. Kuesioner dilakukan uji validitas dan reliabilitas.

Uji validitas dilakukan dengan tujuan untuk mengetahui sejauh mana skor / nilai / ukuran yang diperoleh menyatakan hasil pengukuran atau pengamatan yang ingin diukur. Suatu alat ukur yang memenuhi uji validitas berarti dapat memberikan hasil pengukuran yang tepat dan akurat serta memiliki ketelitian yang tinggi karena mampu mendeteksi perbedaan perbedaan kecil yang ada pada atribut yang diukurnya (Sutalaksana, 1979). Dalam penelitian uji validitas menggunakan teknik pengujian Pearson dengan taraf kepercayaan 95\% dan tingkat ketelitian $(\alpha)$ sebesar 0,05. Nilai yang digunakan dalam penelitian ini jika nilai koefisien $r$ yang diperoleh $>r$ tabel, berarti valid dan jika < $r$ tabel berarti tidak valid. Uji validitas menggunakan rumus Bivariate Pearson (Korelasi Pearson Product Moment). Analisis ini dengan cara mengkorelasikan masing-masing skor item dengan skor total menggunakan rumus sebagai berikut :

$$
r_{x y}=\frac{n\left(\sum X Y\right)-\left(\sum X\right)\left(\sum Y\right)}{\sqrt{\left[n \sum X^{2}-\left(\sum X\right)^{2}\right]\left[n \sum Y^{2}-\left(\sum Y\right)^{2}\right]}}
$$

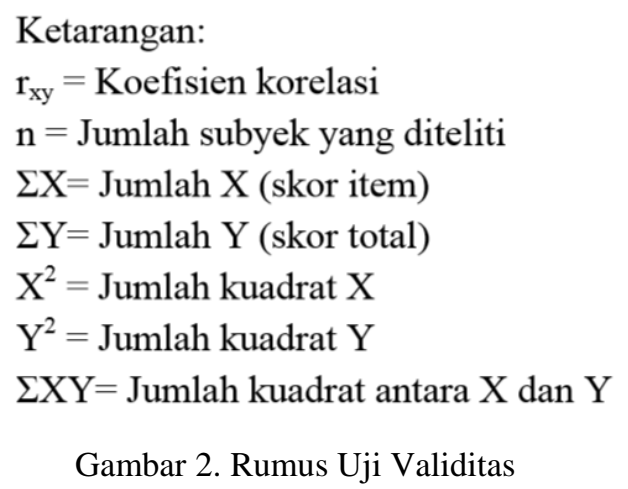

Metode yang digunakan dalam uji reliabilitas adalah metode Cronbach's Alpha. Metode Cronbach's Alpha sangat cocok digunakan pada skor berbentuk skala atau skor rentangan. Pengujian reliabilitas biasanya menggunakan batasan tertentu seperti 0,6. Reliabilitas kurang dari 0,6 adalah kurang baik, sedangkan 0,7 dapat diterima dan diatas 0,8 adalah baik. Pengujian Reliabilitas menggunkan alat ukur berupa teknik Alpha Cronbach dengan rumus sebagai berikut (Priyatno, 2010) :

$$
\begin{aligned}
& r_{11}=\left\{\frac{k}{k-1}\right\}\left\{1-\frac{\sum \alpha_{b}^{2}}{\alpha_{1}^{2}}\right\} \\
\text { Dimana: } & \\
\mathrm{r}_{11}= & \text { Koefisien reliabilitas } \\
\mathrm{k} & =\text { Banyaknya item dan tes } \\
\sum \alpha_{b}^{2}= & \text { Varians skor tes } \\
\alpha_{1}^{2} & =\text { Varian total }
\end{aligned}
$$

Gambar 3. Rumus Uji Realibitas

Dalam penelitian ini uji validitas dan reabilitas menggunakan aplikasi Microsoft excel. 
Perhitungan kesenjangan merupakan suatu perhitungan untuk mengetahui apakah terdapat kesenjangan antara variabel layanan yang diteliti, disamping itu juga mengetahui atribut apa saja yang mengalami kesenjangan. Cara perhitungannya yaitu dengan menghitung kesenjangan (gap) yang terjadi antara dua variabel yang diteliti yaitu menghitung nilai rata-rata persepsi dengan nilai rata-rata harapan (gap).

Setelah dilakukan pengolahan data dengan cara menghitung nilai kesenjangan (gap), maka dapat ditentukan nilai kepuasan negatif $(<0)$ menunjukan adanya kesenjangan antara harapan dan persepsi, sebaliknya bila nilai kepuasan positif $(>0)$ menunjukan kualitas pelayanan melebihi tingkat kepuasan konsumen. Bila nilai kepuasan sesuai $(=0)$ menunjukan kualitas pelayanan telah sesuai dengan harapan.

Setelah dilakukan analisis data diperoleh atribut-atribut dari dimensi-dimensi tingkat kualitas pelayanan yang perlu diperbaiki atau ditingkatkan kembali agar kepuasan mitra atau pelanggan terpenuhi. Dalam hal ini yang perlu dilakukan dalam peningkatan kualitas pelayanan adalah atribut kualitas pelayanan yang mendapatkan kesenjangan antara harapan dan persepsi. Adapun dalam menganalisis akar penyebab masalah dengan menggunakan why why analysis (analisa kenapa kenapa) yang merupakan suatu metode yang digunakan dalam root cause analysis dalam rangka unntuk problem solving yaitu mencari akar suatu masalah atau penyebab dari defect supaya sampai ke akar penyebab masalah.

Dalam membuat usulan perbaikan pada penelitian ini dengan cara merencanakan langkah-langkah implementasi kaizen yaitu $5 \mathrm{~W}+1 \mathrm{H}$ yang terdiri dari what (apa), why (mengapa), where (dimana), when (kapan), who (siapa) dan how (bagaimana) untuk memperoleh data-data dalam melakukan perbaikan. Dalam Perencanaan implementasi Kaizen ini di dasarkan dari hasil identifikasi masalah yang sudah di dapatkan.

Dari usulan perbaikan ini diharapkan dapat membantu pihak manajemen dalam meningkatkan kualitas pelayanan yang sesuai dengan harapan yang diinginkan oleh mitra perusahaan.

Pihak pengawas dan manajemen diharapkan selalu dapat mengevaluasi kinerja pelayanannya tidak hanya saat ini tetapi untuk seterusnya agar tingkat persepsi mitra perusahaan dapat selalu terkontrol dengan baik. Hal ini penting dilakukan karena pelayanan yang baik akan mendapatkan persepsi yang positif dari mitra perusahaan dan menciptakan kepuasan terhadap pelayanan yang diberikan.

\section{HASIL DAN PEMBAHASAN}

PT. Media Purna Engineering adalah sebuah perusahaan yang bergerak dibidang pelayanan jasa (kontraktor) yang melayani perusahaan menengah dan perusahaan besar, baik swasta atau pemerintahan. Sebagai perusahaan pelayanan jasa yang didirikan pada tahun 2013, PT. Media Purna Engineering menyediakan solusi bisnis yang inovatif kepada perusahaan yang menjadi mitranya, yang mana selalu mengutamakan mutu serta kepercayaan demi kelangsungan bisnis yang harmonis dan berkelanjutan.

PT. Media Purna Engineering saat ini berfokus terhadap suplay tenaga kerja dibidang perawatan mechanic rotating, sistem hidrolik, kontruksi, dan piping, mulai dari level helper sampai dengan level supervisor, disamping perusahaan juga melayani kebutuhan permintaan mitra perusahaan.

PT. Media Purna Engineering dalam menjalankan bisnis didukung oleh sumber daya yang berkuaitas dan berpengalaman dalam bidangnya. Karena perusahaan yakin, hanya dengan sumber daya yang tinggi dapat menghasilkan kualitas pekerjaan dan pelayanan yang baik sesuai dengan yang diharapkan mitra bisnis perusahaan.

\section{UJI VALIDITAS DAN REABILITAS}

Hasil Kuesioner yang telah disebar kemudian diuji tingkat validitas dan reliabilitas dengan menggunakana software Microsoft Excel. Valid berarti instrumen tersebut dapat digunakan untuk

JIM, Vol. 2, No. 2, Juli 2017, pp.39-49 
mengukur apa yang hendak diukur. Jika $r$ hitung $\geq \mathrm{r}$ tabel maka instrumen atau item-item pertanyaan berkorelasi signifikan terhadap skor total (dinyatakan valid). Alat ukur yang reliabel menghasilkan data yang dapat dipercaya. Jika koefisien lebih dari 0,905 maka instrumen dinyatakan reliabel. Keseluruhan hasil menunjukkan bahwa semua variabel telah valid dan reliabel.

\section{ANALISIS SERVQUAL}

Perhitungan kesenjangan ( $g a p$ ) dapat dilihat sebagai berikut :

Tabel 1. Nilai Kesenjangan (Gap)

\begin{tabular}{|c|c|c|c|c|}
\hline \multicolumn{2}{|c|}{ DIMENSI TANGIBLES } & \multirow{2}{*}{$\begin{array}{l}\text { RATA- } \\
\text { RATA } \\
\text { PERSEPSI } \\
4.57\end{array}$} & \multirow{2}{*}{\begin{tabular}{|l|} 
RATA- \\
RATA \\
HARAPAN
\end{tabular}} & \multirow{2}{*}{$\begin{array}{l}\boldsymbol{G A P} \boldsymbol{P} \\
0\end{array}$} \\
\hline 1 & $\begin{array}{l}\text { Penampilan pekerja (mengunakan } \\
\text { perlengkapan safety) saat bekerja }\end{array}$ & & & \\
\hline 2 & $\begin{array}{l}\text { Pekerja selalu ditempat bila } \\
\text { dibutuhkan }\end{array}$ & 3,71 & 3,71 & 0 \\
\hline 3 & $\begin{array}{l}\text { Pekerja selalu memakai } \begin{array}{r}\text { sabuk } \\
\text { pengaman ketika } \\
\text { diketinggian }\end{array} \\
\text { bekerja }\end{array}$ & 4,29 & 4,14 & 0,15 \\
\hline 4 & $\begin{array}{lll}\text { Kelengkapan } & \text { dan } & \text { kesiapan } \\
\text { peralatan kerja } & & \\
\end{array}$ & 2,29 & 4,43 & $-2,14$ \\
\hline 5 & $\begin{array}{l}\text { Pekerja selalu memperhatikan } \\
\text { kebersihan dan } \\
\text { lingkungan kerja }\end{array}$ & 3,14 & 2,86 & 0,28 \\
\hline \multicolumn{2}{|c|}{ DIMENSI RELIABILITY } & $\begin{array}{l}\text { RATA- } \\
\text { RATA } \\
\text { PERSEPSI }\end{array}$ & $\begin{array}{l}\text { RATA- } \\
\text { RATA } \\
\text { HARAPAN }\end{array}$ & $G A P$ \\
\hline 6 & $\begin{array}{l}\text { Kesesuaian } \\
\text { diberikan telayanan yang } \\
\text { kebutuhan }\end{array}$ & 4,29 & 4 & 0,29 \\
\hline 7 & $\begin{array}{l}\text { Keandalan pekerja dalam } \\
\text { melaksanakan tugas yang diberikan }\end{array}$ & 4 & 4 & 0 \\
\hline 8 & $\begin{array}{l}\text { Memberikan pelayanan secara } \\
\text { tepat }\end{array}$ & 3,71 & 3,43 & 0,28 \\
\hline 9 & $\begin{array}{l}\text { Ketepatan waktu dalam } \\
\text { menyelesaikan suatu pekerjaan }\end{array}$ & 3,89 & 3,89 & 0 \\
\hline 10 & $\begin{array}{lll}\text { Kemampuan pekerja } & \text { untuk } \\
\text { melaksanakan pekerjaan } & \text { tanpa } \\
\text { melakukan kesalahan } & \end{array}$ & 4,43 & 4,43 & 0 \\
\hline \multicolumn{2}{|c|}{ DIMENSI RESPONSIVENESS } & $\begin{array}{l}\text { RATA- } \\
\text { RATA } \\
\text { PERSEPSI }\end{array}$ & $\begin{array}{l}\text { RATA- } \\
\text { RATA } \\
\text { HARAPAN }\end{array}$ & GAP \\
\hline 11 & $\begin{array}{l}\text { Kecepatan pekerja dalam } \\
\text { menanggapi permasalahan kerja }\end{array}$ & 3,71 & 3,57 & 0,14 \\
\hline
\end{tabular}




\begin{tabular}{|c|c|c|c|c|}
\hline 12 & $\begin{array}{l}\text { Cepat dalam memberikan informasi } \\
\text { genting }\end{array}$ & 3,86 & 3,86 & 0 \\
\hline 13 & $\begin{array}{l}\text { Pekerja langsung memberikan } \\
\text { bantuan saat diminta bantuan }\end{array}$ & 4,43 & 4,29 & 0,14 \\
\hline 14 & $\begin{array}{l}\text { Pekerja tidak pernah terlalu sibuk } \\
\text { sehingga selalu dapat merespon } \\
\text { permintaan }\end{array}$ & 4,43 & 4,43 & 0 \\
\hline 15 & Cepat dalam memberikan solusi & 3,29 & 3,86 & $-0,57$ \\
\hline \multicolumn{2}{|c|}{ DIMENSI ASSURANCE } & $\begin{array}{l}\text { RATA- } \\
\text { RATA } \\
\text { PERSEPSI }\end{array}$ & $\begin{array}{l}\text { RATA- } \\
\text { RATA } \\
\text { HARAPAN }\end{array}$ & GAP \\
\hline 16 & $\begin{array}{l}\text { Pekerja selalu berhati-hati dalam } \\
\text { melaksanakan pekerjaan }\end{array}$ & 4,71 & 4,43 & 0,28 \\
\hline 17 & $\begin{array}{l}\text { Pekerja selalu konsisten bersikap } \\
\text { sopan }\end{array}$ & 4 & 4 & 0 \\
\hline 18 & $\begin{array}{l}\text { Pekerja mempunyai pengetahuan } \\
\text { dan keterampilan yang diperlukan } \\
\text { pekerjaan }\end{array}$ & 3,29 & 3,57 & $-0,28$ \\
\hline 19 & $\begin{array}{l}\text { Menginformasikan } \text { hasil dalam } \\
\text { setiap pekerjaan }\end{array}$ & 4 & 4 & 0 \\
\hline 20 & $\begin{array}{l}\text { Memberikan evaluasi dari setiap } \\
\text { hasil pekerjaan }\end{array}$ & 4,29 & 4,14 & 0,15 \\
\hline \multicolumn{2}{|c|}{ DIMENSI EMPATHY } & $\begin{array}{l}\text { RATA- } \\
\text { RATA } \\
\text { PERSEPSI }\end{array}$ & $\begin{array}{l}\text { RATA- } \\
\text { RATA } \\
\text { HARAPAN }\end{array}$ & GAP \\
\hline 21 & $\begin{array}{l}\text { Memberikan perhatian secara } \\
\text { khusus terhadap setiap plane yang } \\
\text { dikerjakan }\end{array}$ & 4 & 3,71 & 0,29 \\
\hline 22 & $\begin{array}{l}\text { Kepedulian pekerja terhadap } \\
\text { keluhan-keluhan dari PT. Krakatau } \\
\text { Steel (Persero) Tbk }\end{array}$ & 3,43 & 3,14 & 0,29 \\
\hline 23 & $\begin{array}{l}\text { Kesesuaian hari dan jam kerja } \\
\text { dengan waktu kerja PT. Krakatau } \\
\text { Steel (Persero) Tbk }\end{array}$ & 3,71 & 3,57 & 0,14 \\
\hline 24 & $\begin{array}{l}\text { Pemahaman pekerja terhadap } \\
\text { kebutuhan dalam bekerja }\end{array}$ & 4 & 3,43 & 0,57 \\
\hline 25 & $\begin{array}{l}\text { Memberikan kesan yang baik } \\
\text { dalam setiap pekerjaan }\end{array}$ & 4,43 & 4,43 & 0 \\
\hline
\end{tabular}


Dari hasil perhitungan kesenjangan (gap) terdapat 3 atribut kepuasan negatif, 10 atribut kepuasan sesuai, dan 12 atribut kepuasan positif. Adapun atribut dan dimensi yang mendapatkan kepuasan negatif adalah sebagai berikut :

\section{Tangibles}

Pada dimensi ini terdapat 1 atribut yang mendapatkan kepuasan negatif yaitu pada atribut ke 4 dengan pernyataannya mengenai kelengkapan dan kesiapan peralatan kerja.

\section{Responsiveness}

Pada dimensi ini terdapat 1 atribut yang mendapatkan kepuasan negatif yaitu pada atribut ke 15 dengan pernyataannya mengenai kecepatan dalam memberikan solusi pada pekerjaan.

\section{Assurance}

Pada dimensi ini terdapat 1 atribut yang mendapatkan kepuasan negatif yaitu pada atribut ke 18 dengan pernyataannya mengenai pekerja mempunyai pengetahuan dan keterampilan yang diperlukan pekerjaan.

Adapun dalam menganalisis akar penyebab masalah dengan menggunakan why why analysis (analisa kenapa kenapa) yang merupakan suatu metode yang digunakan dalam root cause analysis dalam rangka unntuk problem solving yaitu mencari akar suatu masalah atau penyebab dari defect supaya sampai ke akar penyebab masalah. Analisis penyebab masalah dapat dilihat pada Tabel 2.

Tabel 2. Why Why Analysis

\begin{tabular}{|c|c|c|c|}
\hline \multicolumn{4}{|c|}{ TANGIBLES } \\
\hline $4 M+1 E$ & Why1 & Why2 & Why3 \\
\hline $\begin{array}{l}\text { Machine } \\
\text { (Alat) }\end{array}$ & $\begin{array}{lll}\text { Peralatan } & \text { kerja } & \text { tidak } \\
\text { lengkap } & & \end{array}$ & $\begin{array}{llr}\text { Tidak } & \text { ada } & \text { penambahan } \\
\text { peralatan baru serta adanya } \\
\text { peralatan } & \text { yang hilang dan } \\
\text { rusak } & & \\
\end{array}$ & $\begin{array}{l}\text { Kurangnya perawatan dan } \\
\text { pengecekan kelengkapan } \\
\text { terhadap alat yang telah } \\
\text { digunakan }\end{array}$ \\
\hline $\begin{array}{l}\text { Man } \\
\text { (Manusia) }\end{array}$ & $\begin{array}{l}\text { Kelalaian pekerja dalam } \\
\text { menggunakan dan } \\
\text { menyimpan peralatan kerja } \\
\text { sehingga peralatan rusak } \\
\text { dan hilang }\end{array}$ & $\begin{array}{l}\text { Kurangnya kesadaran pekerja } \\
\text { dalam merawat dan menjaga } \\
\text { peralatan }\end{array}$ & $\begin{array}{l}\text { Hukuman yang kurang tegas } \\
\text { bagi yang merusak atau } \\
\text { menghilangkan peralatan }\end{array}$ \\
\hline $\begin{array}{l}\text { Metodhe } \\
\text { (Cara) }\end{array}$ & $\begin{array}{l}\text { Tidak adanya peraturan } \\
\text { tentang penggunaan dan } \\
\text { perawatan peralatan }\end{array}$ & $\begin{array}{lr}\text { Tidak } & \begin{array}{r}\text { dibuatkannya } \\
\text { penjadwalan } \\
\text { peralatan kerja }\end{array} \\
\end{array}$ & - \\
\hline $\begin{array}{l}\text { Environm } \\
\text { ent } \\
\text { (Lingkung } \\
\text { an) }\end{array}$ & $\begin{array}{lr}\text { Gudang } & \text { tempat } \\
\text { penympanan } & \text { peralatan } \\
\text { yang tidak rapi } & \end{array}$ & $\begin{array}{l}\text { Tempat penyimpanan yang } \\
\text { tidak tertata baik }\end{array}$ & $\begin{array}{l}\text { Tidak adanya tempat khusus } \\
\text { untuk menyimpan peralatan } \\
\text { yang sejenis }\end{array}$ \\
\hline \multicolumn{4}{|c|}{ RESPONSIVENESS } \\
\hline $4 M+1 E$ & Whyl & Why2 & Why3 \\
\hline $\begin{array}{l}\text { Man } \\
\text { (Manusia) }\end{array}$ & $\begin{array}{l}\text { Pekerja kurang } \quad \begin{array}{c}\text { cepat } \\
\text { dalam memberikan } \\
\text { permasalahan kerja }\end{array} \\
\end{array}$ & \begin{tabular}{lrr} 
Kurangnya & \multicolumn{2}{c}{ pemahaman } \\
terhadap & masalah yang \\
dihadapi & & \\
\end{tabular} & $\begin{array}{ll}\text { Kurangnya penjelasan } \\
\text { tentang pekerjaan yang akan } \\
\text { dilakukan }\end{array}$ \\
\hline $\begin{array}{l}\text { Metodhe } \\
\text { (Cara) }\end{array}$ & $\begin{array}{l}\text { Kurangnya pelatihan } \\
\text { tentang bagamana cara } \\
\text { mengatasi permasalahan } \\
\text { susatu pekerjaan }\end{array}$ & $\begin{array}{l}\text { Pengaturan waktu pelatihan } \\
\text { yang tidak tepat }\end{array}$ & $\begin{array}{l}\text { Tidak adanya penjadwalan } \\
\text { pelatihan }\end{array}$ \\
\hline
\end{tabular}




\begin{tabular}{|c|c|c|c|}
\hline \multicolumn{4}{|c|}{ ASSURANCE } \\
\hline $4 M+1 E$ & Why1 & Why2 & Why3 \\
\hline $\begin{array}{l}\text { Man } \\
\text { (Manusia) }\end{array}$ & $\begin{array}{lr}\text { Pekerja kurang } & \text { memeliki } \\
\text { pengetahuan } & \text { dan } \\
\text { keterampilan } & \text { yang } \\
\text { diperlukan pekerjaan } & \\
\end{array}$ & $\begin{array}{l}\text { Banyaknya pekerja helper atau } \\
\text { non skill yang baru, yang } \\
\text { belum mempunyai } \\
\text { keterampilan kerja }\end{array}$ & $\begin{array}{l}\text { Kurangnya pekerja helper } \\
\text { yang berpengalaman }\end{array}$ \\
\hline $\begin{array}{l}\text { Metodhe } \\
\text { (Cara) }\end{array}$ & $\begin{array}{lr}\text { Kurangnya } & \text { pelatihan } \\
\text { pengetahuan } & \text { dan } \\
\text { keterampilan } & \text { kerja kepada } \\
\text { pekerja baru } & \end{array}$ & $\begin{array}{l}\text { Pengaturan waktu pelatihan } \\
\text { yang tidak tepat }\end{array}$ & $\begin{array}{l}\text { Tidak adanya penjadwalan } \\
\text { pelatihan }\end{array}$ \\
\hline
\end{tabular}

Usulan perbaikan pada penelitian ini dengan cara merencanakan langkah-langkah implementasi kaizen yaitu $5 \mathrm{~W}+1 \mathrm{H}$ yang terdiri dari what (apa), why (mengapa), where (dimana), when (kapan), who (siapa) dan how (bagaimana) untuk memperoleh data-data dalam melakukan perbaikan. Dalam Perencanaan implementasi Kaizen ini di dasarkan dari hasil identifikasi masalah yang sudah di dapatkan yaitu ada 3 atribut dari 25 atribut yang harus dilakukan peningkatan atau pengembangan dan untuk melakukan ini langkah selanjutnya adalah menentukan acuan untuk bisa memperbaiki dari ke 3 atribut tersebut guna meningkatkan kualitas pelayanan dan menurunkan tingkat keluhan. Usulan perbaikan dapat dilihat pada Tabel 3.

Tabel 3. $5 \mathrm{~W}+1 \mathrm{H}$

\begin{tabular}{|c|c|c|c|c|c|c|}
\hline Dimensi & What & Why & Where & When & Who & How \\
\hline $\begin{array}{l}\text { Tangibl } \\
\text { es }\end{array}$ & $\begin{array}{l}\text { - Kurangny } \\
\text { a } \\
\text { perawatan } \\
\text { dan } \\
\text { pengeceka } \\
\text { n } \\
\text { kelengkap } \\
\text { an } \\
\text { terhadap } \\
\text { alat yang } \\
\text { telah } \\
\text { digunakan } \\
\\
\text { - Hukuman } \\
\text { yang } \\
\text { kurang } \\
\text { tegas bagi } \\
\text { yang } \\
\text { merusak } \\
\text { atau } \\
\text { menghilan } \\
\text { gkan } \\
\text { peralatan } \\
\end{array}$ & $\begin{array}{l}\text { - Supaya } \\
\text { peralata } \\
\text { n yang } \\
\text { telah } \\
\text { digunak } \\
\text { an } \\
\text { selalu } \\
\text { lengkap } \\
\\
\\
\\
\text { Supaya } \\
\text { para } \\
\text { pekerja } \\
\text { lebih } \\
\text { bertang } \\
\text { gung } \\
\text { jawab } \\
\text { terhada } \\
\text { p } \\
\text { peralata } \\
\text { n yang } \\
\text { telah } \\
\text { digunak } \\
\text { an } \\
\text { Supaya } \\
\text { waktu } \\
\text { perawat } \\
\text { an lebih } \\
\text { terenca } \\
\text { na } \\
\text { dalam } \\
\text { melaku } \\
\text { kan }\end{array}$ & $\begin{array}{l}\text { - Gudang } \\
\text { tempat } \\
\text { penyimp } \\
\text { anan } \\
\text { peralata } \\
\text { n kerja } \\
\\
\text { - Kantor } \\
\\
\\
\text { Kantor } \\
\\
\text { - } \\
\text { penyimp } \\
\text { anan } \\
\text { tempatata } \\
\end{array}$ & $\begin{array}{l}\text { - Setelah } \\
\text { melakuka } \\
\mathrm{n} \\
\text { perawatan } \\
\text { peralatan } \\
\text { kerja } \\
\\
\\
\\
\text { - Ketika }\end{array}$ & $\begin{array}{l}\text { - Pekerja } \\
\text { dan } \\
\text { Leader }\end{array}$ & $\begin{array}{l}\text { - Memberik } \\
\text { an } \\
\text { hukuman } \\
\text { yang tegas } \\
\text { bagi } \\
\text { pekerja } \\
\text { yang } \\
\text { merusak } \\
\text { atau } \\
\text { menghilan } \\
\text { gkan } \\
\text { peralatan } \\
\text { kerja } \\
\\
\\
\text { - Membuat } \\
\text { jedwal } \\
\text { perawatan } \\
\text { kerja }\end{array}$ \\
\hline
\end{tabular}




\begin{tabular}{|c|c|c|c|c|c|c|}
\hline & $\begin{array}{l}\text { kerja } \\
\text { tidak } \\
\text { adanya } \\
\text { tempat } \\
\text { khusus } \\
\text { untuk } \\
\text { menyimp } \\
\text { an } \\
\text { peralatan } \\
\text { yang } \\
\text { sejenis }\end{array}$ & 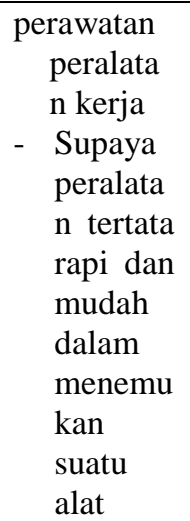 & & $\begin{array}{l}\text { an } \\
\text { peralatan } \\
\text { kerja }\end{array}$ & & $\begin{array}{l}\text { - Membuat } \\
\text { tempat- } \\
\text { tempat } \\
\text { khusus } \\
\text { untuk } \\
\text { peralatan } \\
\text { yang } \\
\text { sejenis }\end{array}$ \\
\hline $\begin{array}{l}\text { Responsiven } \\
\text { ess }\end{array}$ & $\begin{array}{l}\text { - Kurangny } \\
\text { a } \\
\text { penjelasa } \\
\mathrm{n} \text { tentang } \\
\text { pekerjaan } \\
\text { yang akan } \\
\text { dilakukan } \\
\\
\\
\\
\text { - tidak } \\
\text { adanya } \\
\text { penjadwal } \\
\text { an } \\
\text { pelatihan }\end{array}$ & $\begin{array}{l}\text { - Supaya } \\
\text { para } \\
\text { pekerja } \\
\text { mengerti } \\
\text { pekerjaa } \\
\text { n dan } \\
\text { permasa } \\
\text { lahan } \\
\text { yang } \\
\text { akan } \\
\text { dihadapi } \\
\text { dan } \\
\text { diselesai } \\
\text { kan } \\
\text { - Supaya } \\
\text { waktu } \\
\text { pelatiha } \\
\text { n lebih } \\
\text { terencan } \\
\text { a dalam } \\
\text { memberi } \\
\text { kan } \\
\text { pelatiha } \\
\text { n } \\
\text { mengen } \\
\text { ai } \\
\text { permasa } \\
\text { lahan } \\
\text { kerja } \\
\text { yang } \\
\text { akan } \\
\text { dihadapi }\end{array}$ & $\begin{array}{ll}- & \text { Temp } \\
\text { at } \\
\text { floati } \\
n g \\
\text { masin } \\
\text { g- } \\
\text { masin } \\
\text { g } \\
\text { peker } \\
\text { ja } \\
\\
\\
\\
\\
\text { - Kant } \\
\text { or }\end{array}$ & $\begin{array}{l}\text { - } \begin{array}{l}\text { Sebelum } \\
\text { melaksa } \\
\text { nakan } \\
\text { pekerjaa } \\
\text { n }\end{array} \\
\\
\\
\\
\\
\\
\text { - Setelah } \\
\text { melaksa } \\
\text { nakan } \\
\text { pekerjaa } \\
\text { n }\end{array}$ & $\begin{array}{l}\text { - Supervis } \\
\text { or dan } \\
\text { Leader } \\
\\
\\
\\
\text { - Supervis } \\
\text { or }\end{array}$ & $\begin{array}{l}\text { - } \text { Melakuka } \\
\mathrm{n} \\
\text { penjelasa } \\
\mathrm{n} \quad \text { ata } \\
\text { pengenala } \\
\mathrm{n} \quad \text { area } \\
\text { tentang } \\
\text { yang akan } \\
\text { dikerjaka } \\
\mathrm{n} \\
\\
\\
\\
\text { Membuat } \\
\text { jadwal } \\
\text { pelatihan } \\
\text { tentang } \\
\text { cara } \\
\text { mengatasi } \\
\text { permasala } \\
\text { han kerja }\end{array}$ \\
\hline Assurance & $\begin{array}{l}\text { - Kurangny } \\
\text { a pekerja } \\
\text { helper } \\
\text { yang } \\
\text { berpengal } \\
\text { aman }\end{array}$ & $\begin{array}{l}\text { - Supaya } \\
\text { tenaga } \\
\text { kerja } \\
\text { helper } \\
\text { selalu } \\
\text { terpenuh } \\
\text { i sesuai } \\
\text { kebutuh } \\
\text { an } \\
\text { pekerjaa } \\
\text { n }\end{array}$ & $\begin{array}{l}\text { - Temp } \\
\text { at } \\
\text { floati } \\
n g \\
\text { masin } \\
\text { g- } \\
\text { masin } \\
\text { g } \\
\text { peker } \\
\text { ja }\end{array}$ & $\begin{array}{l}\text { - Sebelum } \\
\text { melaksa } \\
\text { nakan } \\
\text { pekerjaa } \\
\text { n }\end{array}$ & $\begin{array}{l}\text { - Supervis } \\
\text { or }\end{array}$ & $\begin{array}{l}\text { - Melakuka } \\
\mathrm{n} \\
\text { perekruta } \\
\mathrm{n} \text { pekerja } \\
\text { helper } \\
\text { yang } \\
\text { berpengal } \\
\text { aman }\end{array}$ \\
\hline
\end{tabular}




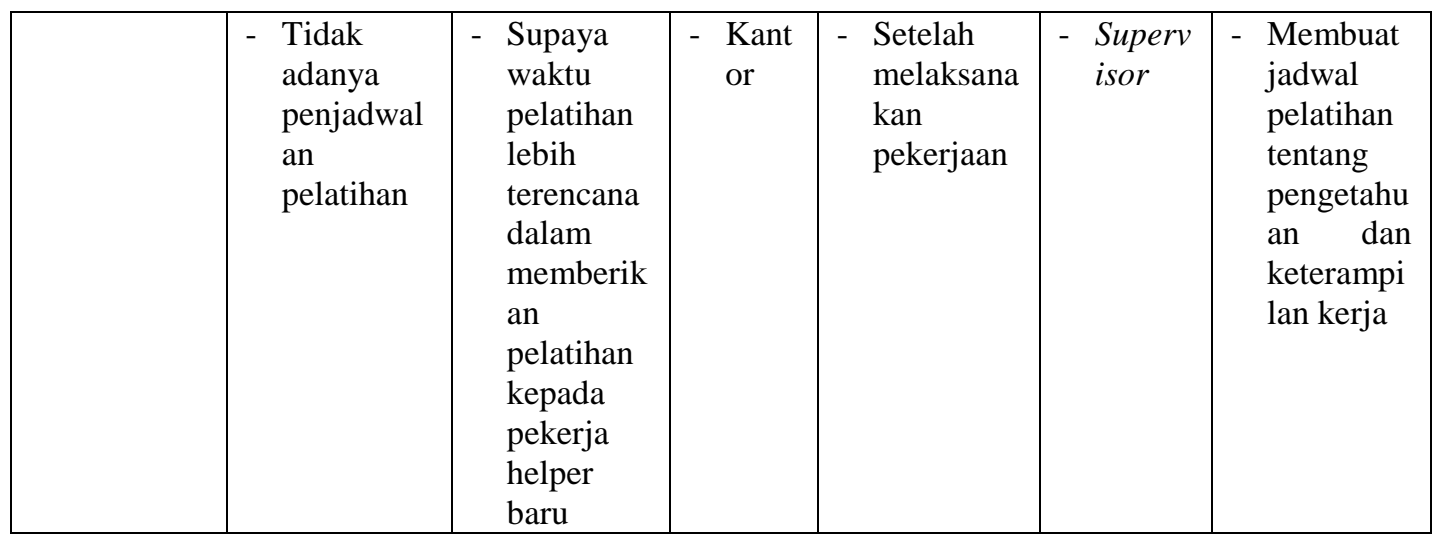

\section{KESIMPULAN DAN SARAN}

\section{Kesimpulan}

Berdasarkan hasil penelitian yang diperoleh oleh peneliti untuk mengetahui kualitas pelayanan PT. Media Purna Enginering area PT. Krakatau Steel (Persero) Tbk, maka dapat disimpulkan bahwa kualitas pelayanan PT. Media Purna Enginering area PT. Krakatau Steel (Persero) tergolong baik. Dari semua dimensi yang digunakan penulis untuk peneliti, yakni Tangibles, Reliability, Responsiveness, Assurance, dan Empathy pada harapan dan persepsi banyak yang sesuai, artinya pelayanan yang diberikan banyak yang sudah memenuhi harapan mitra perusahaan. Namun masih ada yang perlu diperbaiki atau ditingkatkan kembali kualitas pelayanannya karena masih terdapat kualitas pelayanan yang belum memenuhi harapan mitra.

Terdapat tiga dimensi dan tiga atribut kualitas pelayanan yang perlu diperbaiki atau ditingkatkan kembali oleh PT. Media Purna Engineering dari hasil penelitian ini diantaranya adalah kelengkapan dan kesiapan peralatan kerja, cepat dalam memberikan solusi, pekerja mempunyai pengetahuan dan keterampilan yang diperlukan pekerjaan. Adapun yang sangat perlu lebih ditingkatkan kembali adalah kelengkapan dan kesiapan peralatan kerja karena mendapat nilai kesenjangan (gap) paling rendah dari pada atribut-atribut kualitas pelayanan lainnya.

\section{Saran}

Adapun saran yang diajukan oleh penulis berdasarkan kesimpulan diatas sebagai berikut :

1. Penambahan peralatan kerja guna kelengkapan dan kesiapan alat-alat dalam bekerja.

2. Keandalan pekerja dalam melaksanakan tugas yang diberikan lebih ditingkatkan kembali seperti memberikan training atau pelatihan untuk meningkatkan pengetahuan dan keterampilan kerja.

3. Pekerja sebaiknya lebih cepat dan tanggap dalam menyikapi setiap permasalahan kerja, sehingga dapat dengan cepat memberikan solusi permasalahan. 


\section{DAFTAR PUSTAKA}

Ariani, D.W, 2003, Manajemen Kualitas: $\quad$ Pendekatan Sisi Kualitatif, Jakarta: Ghalia Indonesia.

Gasperz, Vincent, 1997, Manajemen Kualitas, $\quad$ Penerapan $\quad$ Konsep-Konsep Kualitas dalam Manajemen Bisnis Total. Jakarta: $\quad$ PT Gramedia halaman.

Gronroos, C. 1990, Servie Management andMarketing: managing the Moment of Truth in Servies Competition. Lexington, Massachutess.

Haeril, Muhammad. 2011. Kualitas Pelayanan PLN Ranting Rappang Kec. Pancarijang Kab. Sidrap [Online]. Tersedia: http://repostory.uhnas.ac.id/handle/123 6789/226.

Jasfar, Farida, 2005. Manajemen Jasa Pendekatan Terpadu. Bogor: Ghalia Indonesia.

Kotler, Philip., Susanto, AB. 2000. Manajemen $\quad$ Pemasaran di Indonesia. Jakarta: Salemba Empat.

Lupiyoadi, Rambat, 2001. Manajemen $\quad$ Pemasaran Jasa, Jakarta: Salemba Empat.

Moenir, H. A. S, 2006, Manajemen Pelayanan Umum di Indonesia, Jakarta: Bumi Aksara.

Mulyana, 2002. Kepuasan Pelanggan sebagai Pengukuran, dan Strategik: EKOBIS.

Keunggulan Daya Saing : Konsep,

Payne, Adrian. 1993. Pemasaran Jasa. Yogyakarta. Penerbit Andi.

Parasuraman, A; Valarie A. Zeithaml; and Leonard L. Berry, 1985. Problem and Stratigies in Service Marketing, Journal of marketing.

Priyatno, Duwi. 2010. Paham Analisa Statistik Data Dengan SPSS. Yogyakarta: Mediakom.

Sampara, Lukman, 2000, Manajemen Kualitas $\quad$ Pelayanan, Jakarta: STIA LAN Press.

Sanapiah, Azis, 2000. Pelayanan yang Berorientasi kepada Kepuasan Masyarakat, Jurnal Administrasi Negara, vol.6 nomor 1.

Santya, Meryana. 2014. Penilaian KepuasanKonsumen Terhadap Kualitas Pelayanan Menggunakan Metode Servqual (Service Quality) dan Six Sigma (Studi Kasus Pada RestoranDahlia Pasuruan [Online]. Tersedia: http://www.skripsitip.staff.ub.ac.id/files/ 014/06/Jurnal-Meryana-Santya- $\quad$ P.pdf.

Supranto, Johanes, 1997. Pengukuran Tingkat Kepuasan Pelanggan, Jakarta: Rineka Cipta.

Sulistyo, Heru. 1999. Hubungan antara Kualitas dan Kepuasan Pelanggan dalam Pembentukan Intensi Pembelian Pelanggan: Studi pada Empat Industri Jasa di Semarang. Jurnal Bisnis Strategi.

Sugiyono, 2006, Statistika untuk Penelitian, Bandung: Alfabeta.

Sutalaksana, Iftikar, dkk, 1979, Teknik Tata Cara Kerja. Bandung: Departemen Teknik Industri-ITB.

Sugiarto, Endar, 1999, Psikologi Pelayanan dalam Industri Jasa.

Tjiptono, Fandy, 1996. Manajemen Jasa, Yogyakarta: Andi Offset.

Tjiptono, Fandy. 2006. Manajemen Jasa. Edisi Keempat. Yogyakarta: Penerbit Andi Offset 